\title{
Outward Foreign Direct Investment of Chinese Enterprises: Review and Analysis \\ Yanan Wang*
}

School of Engineering, Deakin University, Waurn Ponds campus, Geelong, Australia

\begin{abstract}
This paper examines the unique motivations and strategies for outward foreign direct investment (OFDI) undertaken by Chinese multinationals, and addresses the challenges associated with these unique motivations and strategies. The findings show that Chinese OFDI is significantly driven by strategic asset seeking, and state ownership serves as a unique type of ownership advantages. Chinese multinationals typically use aggressive modes such as wholly-owned subsidiaries and acquisitions to enter foreign markets, but the associated challenges of those aggressive modes in post-entry integration are not negligible. This paper provides a comprehensive view on theory of Chinese OFDI and offers practical guidance for Chinese multinationals in their global expansion by outlining the strategies and challenges of Chinese OFDI.
\end{abstract}

Keywords: Foreign direct investment; Business; World Trade Organization; Double door; Open door; Cross-border; Chinese enterprises; Global competition

\section{Introduction}

The past two decades have witnessed rapid growth and remarkable transformation toward industrialization in the Chinese economy $[1,2]$. With the 'open door' policy launched by the central government in 1978, China began the process of integration with the global economy, and this process was accelerated with accession to the World Trade Organization (WTO) [3]. A special phenomenon that has characterized China's development is a recent surge in its outward foreign direct investment (OFDI) [4,5]. After 'go global' was firmly established as a national policy in 2004, more Chinese domestic firms became eager to enter and compete in the international market. The World Investment Report 2014 [6] states that FDI from mainland China reached US\$101 billion in 2013, representing an increase of 18.36 times that in 2014. The Chinese expatriate outflow stock was 812,000 at the end of 2011, an increase of 322,000 people since the end of 2002 [7]. Chinese multinational enterprises (MNEs) hired about 880,000 local employees in host countries, which represents $72.8 \%$ as an employment localization rate; and took 331,780 Chinese employees to work in foreign subsidiaries in 2011 [7]. Many foreign acquisitions by Chinese enterprises such as Lenovo, TCL, and Haier have grabbed headlines of the popular press and business magazines.

Despite significant increase in the amount of Chinese OFDI in recent years, it is noteworthy that many Chinese enterprises fall short of their stated objectives for their overseas operations [8]. Therefore, it is important to review and analyze the OFDI activities of Chinese enterprises, and identify the difficulties which thwart their practices in their international operations [9]. In this paper, I present a framework that analyzes the uniqueness of Chinese enterprises' OFDI activities, including the motivations, strategies and challenges which these organizations face. Based on the discussion, some research questions are proposed to give a better understanding of this phenomenon, and to provide useful guidance to Chinese enterprises' outward expansion through OFDI.

\section{Motivations for Chinese OFDI}

From a traditional perspective, foreign direct investment (FDI) from developed countries was undertaken to exploit cheap labor and raw materials in developing countries, and at the same time offering superior technology or managerial know-how to make profit [10]. Later research on OFDI from developing countries, especially that from emerging markets, identifies that such OFDI is quite different not only because it is undertaken in search of strategic assets such as technology and managerial skills rather than offering them, but also because it has been strongly influenced by home and host country institutional environments [4,11]. As one of the most significant emerging markets, China first went into other developing countries either to utilize its advantages in technology, or to strengthen political affiliations with those developing countries [12]. Recently, more and more Chinese enterprises enter developed countries to pursue strategic assets such as technology and brand $[5,13]$. In addition, China may foster its OFDI with unique features due to the distinct institutional settings of its economy. The existing literature suggests that there are both conventional and idiosyncratic dimensions to Chinese OFDI [3]. The conventional motivations of Chinese OFDI, which are similar to those of other emerging market multinationals (MNEs), can be summarized as following:

- Home government support for going abroad;

- To avoid increasing competitive pressure from global rivals in their backyard;

- Fast change of market conditions and a heightened borderless world economy;

- The latecomer position and their deficiencies in core competencies;

- Entrepreneurial desire to hit the core international markets.

However, as mentioned before, OFDI from Chinese enterprises may have unique characteristics given the large extent of state control

*Corresponding author: Yanan Wang, School of Engineering, Deakin University, Waurn Ponds campus, Geelong, VIC 3216. Australia, Tel: +61 3 99032757; E-mail: Yanan.Wang@deakin.edu.au

Received August 03, 2015; Accepted August 24, 2015; Published August 26 2015

Citation: Wang Y (2015) Outward Foreign Direct Investment of Chinese Enterprises: Review and Analysis. Ind Eng Manage 4: 170. doi:10.4172/21690316.1000170

Copyright: (c) 2015 Wang Y. This is an open-access article distributed under the terms of the Creative Commons Attribution License, which permits unrestricted use, distribution, and reproduction in any medium, provided the original author and source are credited. 
of the Chinese economy. Idiosyncratic features of Chinese OFDI have been identified which include:

- Significantly driven by natural resource-seeking and strategic asset-seeking incentives;

- State ownership may serve as a specific kind of ownership advantages;

- Availability of cheap capital from the state tends to create wasteful OFDI.

First of all, Chinese OFDI is significantly driven by natural resourceseeking and more recently, strategic asset-seeking incentives. Since the 1980s, the Chinese government has required overseas subsidiaries to achieve the goal of raw material access to secure a continual supply for the domestic industrial operations and rapid economic growth. This is because, although China is well endowed with its own natural resources, its per capita availability of resources is very low $[4,14]$. One good example is that the Shanghai Baoshan Iron and Steel Corporation has invested in six Joint Ventures (JVs) in Australia, Brazil, and South America, with the primary intention of procuring the iron ore to back up its own domestic development.

More recently, Chinese MNEs are increasingly interested in acquiring strategic assets such as a globally recognized brand as well as advanced technology to offset their latecomer disadvantages in the global competition $[15,16]$. For example, the Lenovo Group acquired the Personal Computer division of IBM in 2005 and again in 2014 acquired IBM's Intel-based server business to address their disadvantage in brand awareness and international reputation. Through such acquisitions, Chinese MNEs not only obtain technology and brands but also access to foreign distribution channels, managerial know-how and capital markets quickly [16]. In addition, Chinese firms also invested in developed countries to promote their R\&D through mutual learning [17]. For example, Huawei, a Chinese telecom company, has created its vision in Europe as building a more intelligent and connected Europe. Now the company is becoming one of the leading companies in the world through its innovation to suit the telecom market in Europe. These Chinese companies take aggressive OFDI approaches to expand overseas which are quite different from those of Western MNEs that expand overseas in an incrementally fashion based on the accumulation of knowledge and experiences $[12,18]$.

Secondly, the state ownership of some Chinese MNEs can serve as a specific proprietary advantage in their OFDI practices, particularly when they invest in other developing countries [3,19]. Because of China's foreign policy and official development aid agreements with some developing countries, especially those of the African countries, Chinese MNEs may not use OFDI to maximize their profits but may use it as a means to strengthen and promote the political affiliations and co-operations between Chinese and the host country governments $[20,21]$. In such circumstances, state ownership of Chinese MNEs can serve as an advantage. Because on the one hand, the Chinese government would offer these MNEs with financial support to accomplish these official development aid programs, and on the other hand, Chinese MNEs are warmly welcomed by the host country government as a reflection of the friendship between China and these developing countries [22]. As such investment is primarily targeted at helping the host country, to develop its own economy, the host country government would every incentive to offer preferential treatments to have Chinese MNEs, including providing low-cost land, labor as well as supportive policies. Furthermore, Chinese MNEs have developed unique abilities when navigating complex bureaucracies and dealing with opaque political constraints in their home country [23]. Such abilities enable them to mitigate the risk when operating in similar weak institutional settings and thus suit the fellow developing countries quite well [3].

Lastly, Chinese MNEs tend to conduct excessive OFDI with low efficiency, due to the imperfect capital allocation of its domestic capital market. China's high saving rates, the state-control of its national banks, as well as the corporate governance structure all contribute to the distortion of the capital market [23]. For example, with a remarkably high saving rate which accounts for $40 \%$ of the domestic GDP, Morck et al. [3] suggested that China's OFDI surge is probably a manifestation of its inability to reinvest its high savings. In addition, China's dominant state-controlled banks may provide capital at belowmarket rates to Chinese MNEs which may stimulate excessive OFDI when these MNEs try to exploit such financial advantages. Further, because some Chinese senior executives may have patriotism-inspiring initiatives in their OFDI decision, and they may use it as means to achieve their personal political goals, it is possible that wasteful OFDI is conducted without consideration of the firms' long-term viability and development [4].

In summary, the unique features of the motivations of Chinese OFDI are strongly influenced by the Chinese government as well as China's institutional environment. The above discussion reveals that government policies lead to significant natural resource-seeking and strategic assetseeking OFDI. At the same time, Chinese MNEs may utilize their state ownership as an advantage in other developing countries and they have a high likelihood of conducting wasteful OFDI. Together with these unique motivations, there are also distinct strategies taken by Chinese MNEs, which will be discussed in the following section.

\section{Strategies for Chinese OFDI}

There are three entry modes being utilised by Chinese MNEs toward OFDI. These are (1) the international joint ventures (IJVs); (2) the wholly owned overseas subsidiaries; and (3) the cross-border mergers and acquisitions (M\&As). Chinese MNEs used IJVs as a main OFDI strategy prior to 2000, and the wholly owned subsidiaries became prevalent after 2000 [24]. Since 2004, the cross-border M\&As emerge as an increasingly favorite mode of OFDI by Chinese MNEs. According to the Ministry of Commerce (MOC) of China, the amount of OFDI through cross-border M\&As jumps from $\$ 4.8$ billion in 2004, to $\$ 47.4$ billion in 2006 which accounts for $36.7 \%$ of the total OFDI in that year. It is exactly as what the existing literature has suggested: China has entered an era of cross-border M\&As.

\section{The route of IJVs}

IJVs refer to Chinese firms forming a new entity with one or more foreign enterprises, and they benefit from the transfer of capable management skills and knowledge from the continuing, operational relationship with these foreign MNEs [25]. The experience of such inward-internationalization permits the capability procurement of Chinese enterprises which stimulate the subsequent OFDI. For example, Huawei Technologies Co. Ltd. has entered into a number of IJVs---to make $3 \mathrm{G}$ handsets with NEC which is a Japanese information technology enterprise, and also cooperate with Microsoft to make networks that integrate voice, data and video. Now Huawei has established $\mathrm{R} \& \mathrm{D}$ centers in India and it is seriously challenging the global leaders such as Cisco Systems in the field of network and telecommunication equipments. 


\section{The route of wholly owned overseas subsidiaries}

This kind of OFDI is undertaken by establishing new entities in a foreign market [26]. It is initially aimed at gaining international brand recognition or securing product differentiation as ownership advantages to enlarge overseas market [27]. Haier Group provides a good example of such international expansion. Under the global brand building strategy, Haier first built trade and R\&D centers in America. Owning to moving into product differentiation such as manufacture of small refrigerators with study desks particularly for use by students and mini-dishwashers for housewives, Haier successfully exhibits its products in US large chain supermarkets such as Wal-Mart and Sears. In addition, it has introduced new products such as wine coolers and luxurious 'double door' large refrigerators to the US and European markets which helped it win great consumer loyalty. Now Haier is the world's 4th largest white goods manufacturer and has established 30 overseas production factories, 8 design centers and over 58,000 sales agents worldwide [28].

\section{The route of cross-border mergers and acquisitions}

Cross-border mergers and acquisitions (M\&As) refer to the buying, selling and combining of companies from different countries into one business entity [29]. A merger happens when two firms come together and create a single new entity, while an acquisition happens when one company takes over another and make an agreement with the acquired company to establish itself as the new owner [30]. However, such M\&As can be hostile takeovers which are those just beneficial for shareholders but goes against the target company's management and board of directors. Of all the Chinese cross-border M\&A transactions, nearly half have been undertaken by large state-owned enterprises with the intension of securing raw material supplies [4]. Another reason for undertaking OFDI through cross-border M\&As is because they provide a fast route to access advanced technology, R\&D skills as well as reputable brand which will help the acquiring company grow rapidly [26]. It is noticeable that the target of Chinese firms' M\&As mainly focused on developed countries firms who possess such competitive assets. Apart from the Lenovo Group, the Nanjing Automobile provides another good example. With the successful experience of IJVs with several advanced market MNEs, Nanjing Automobile develops its confidence to acquire MG Rover, a mass-production car manufacturer in the British motor industry. This acquisition is undertaken with a strategic intention to upgrade Nanjing Automobile's production line as well as develop its own R\&D capabilities. It is without doubt that Nanjing Automobile access foreign updated technologies, patents and managerial skills quickly [16].

In summary, the cross-border M\&A route as a primary mode of OFDI is favored by an increasing number of Chinese MNEs. Such a mode is carefully selected based on the consideration of firms' strategic goals of seeking various kinds of competitive assets. The distinctive feature of widely using the aggressive investment mode of cross-border M\&As mirror the desire to grow rapidly of Chinese MNEs, and the willingness in retaining their distinctive managerial heritage. However, the risks associated with such investment mode are by no means to be neglected. Serious challenges remain in Chinese firms' OFDI activities which will be discussed in the following section.

\section{Challenges for Chinese OFDI}

The above discussion has identified that cross-border M\&As have become increasingly popular in recent years as a form of Chinese MNEs' OFDI. Although the M\&A mode is seen by many as the fastest and easiest way to expand into a new market, for example, it can provide quick access to local knowledge and business contacts etc, the success of such mode is by no means assured. The real challenge to Chinese MNEs' OFDI activities pertains to post-entry, or post-M\&A integration $[5,8]$.

Challenges of post-entry integration may be attributable to several factors, which mainly focus on the following two issues:

- Differences in culture and managerial practice encountered in a foreign market; and

- Lack of suitably qualified personnel who possess international management skills.

First of all, differences in culture and managerial practice pose the most significant challenge to Chinese MNEs' post-M\&A integration. According to a report from the World Bank, nearly two thirds of Chinese enterprises failed to reach their stated goals when investing overseas. 85 percent of the CEOs of these enterprises admit that 'differences in corporate cultures and managerial styles are the main reasons for failure' $[8,9]$. For example, TCL's President Li has even announced that the failure of the merger between TCL and Alcatel is because of cultural incompatibility---most key talent including senior managers and marketing personnel left the company because they could not adapt to the management approaches of their new Chinese owner. 'it is human-oriented management in Alcatel, while centralized decision-making in Chinese firms'.

Another major challenge is the lack of talent with knowledge of foreign markets and international management skills [5]. The challenge is not simply the amount of human talent but what types of skill sets they have. Sufficient knowledge about the host country, including knowledge of the foreign language, business culture, competition policy and institutional environment, is required as useful skills for managing overseas' operations $[31,32]$. Without the pool of human talent, China's OFDI aspirations will be thwarted and economic growth will slow [9]. For example, Zhang Ruimin, the CEO of Haier, highlights in his article that

"There is a wide gap between Chinese enterprises and major foreign companies - but it isn't mainly a technology gap. The key difference is in management talent" [28].

To sum up, it is arguable that China's OFDI is still in an infant stage and the real challenge is not how to enter a foreign market, but how to manage the integration process after their entry. Accordingly, it is of crucial importance for the Chinese MNEs to effectively and efficiently managing the integration process and using the acquired assets as a springboard to upgrade their capabilities and successfully compete in the international market. In the years to come, we expect significant growth in China's OFDI, especially through cross-border M\&As with the primary intention to procure knowledge and capabilities. However, most studies of Chinese OFDI focus on pre-entry motivations, yet few of those have addressed questions in the post-entry phase, particularly in the post-M\&A integration process. It is without doubt that more research is needed in this particular area. Only by understanding the essential process of post-entry, or post-M\&A integration can we help or guide these Chinese MNEs to grow quicker, and perform better in the global market than it should be.

\section{Conclusion}

This paper reviews and analyzes the existing literature on the OFDI activities of Chinese MNEs, with the primary intention of having a better understanding of Chinese MNEs based on China's unique institutional environment. Therefore, it examines the motivations, 
strategies and challenges of Chinese MNEs, and the primary findings suggest that the OFDI activities of Chinese MNEs differ significantly from that of Western MNEs as well as other emerging market MNEs.

OFDI from Chinese MNEs is not only driven by conventional motivations such as home government support, increasingly competitive domestic competition, latecomer positions in the global competition $[4,14]$, but also driven by idiosyncratic motivations which include: significant natural-recourse seeking as well as strategicasset seeking incentives; State ownership served as a specific kind of ownership advantage in China in the past; and excessive OFDI conducted due to the imperfect capital allocation. Therefore, the uniqueness of Chinese MNEs' OFDI activities is primarily attributed to the unique institutional setting of the Chinese economy such as great extent of state control [20]. From the perspective of strategy, a notable trend is the gradual appearance of using cross-border M\&As as a primary mode for OFDI activities compared to other forms, including IJVs as well as the wholly owned overseas subsidiaries. Although the mode of cross-border M\&As is proposed to be the fastest and easiest way to enter a new market, the real challenge pertains to post-M\&A integration. Significant challenges confronted by Chinese MNEs during their post-M\&A integration are identified which include differences in culture as well as management, and lack of management talent [5].

Chinese MNEs still have a long way to go when it comes to effectively and efficiently integrating the acquired assets into their own business. Although some aspects of the difficulties in post-M\&A integration have been identified, further study of how Chinese MNEs can manage this essential process is likely to be rewarding. This study suggests that there are several questions worthy of further research, namely: "What kinds of difficulties will Chinese managers encounter in the post-M\&A integration, especially when they invest in developed countries?" and "What are the differences between Chinese and typical Western managerial approaches to making decisions, as well as managing subordinates?" Answering these questions may help us to understand the integration process better and accordingly, give us a deep insight of Chinese MNEs' OFDI activities. Exploring the postM\&A integration process of Chinese MNEs will not only contribute to the existing international business literature, but also give useful insights into Chinese MNEs' OFDI practices.

\section{References}

1. Bräutigam D, Tang X (2014) Going Global in Groups: Structural Transformation and China's Special Economic Zones Overseas. World Development 63: 78-91

2. Guthrie D (2012) China and globalization: the social, economic and political transformation of Chinese society. Routledge.

3. Morck R, Yeung B, Zhao M (2008) Perspectives on China's Outward Foreign Direct Investment. Journal of International Business Studies 39: 337-350.

4. Deng P (2013) Chinese outward direct investment research: theoretical integration and recommendations. Management and Organization Review 9 : 513-539.

5. Wang D, Feng T, Freeman S, Fan D, Zhu CJ (2014) Unpacking the skill cross-cultural competence mechanisms: Empirical evidence from Chinese expatriate managers. International Business Review 23: 530-541.

6. UNCTAD (United Nation Conference Trade and Development) (2014) World Investment Report 2014. United Nations, New York.

7. MOFCOM (Ministry of Commerce, People's Republic of China) (2014) Statistical Bulletin of China's Outward Foreign Direct Investment. China Statistics Press, Beijing.

8. Wang D, Freeman S, Zhu CJ (2013) Personality traits and cross-cultural competence of Chinese expatriate managers: A socio-analytic and institutional perspective. International Journal of Human Resource Management 24: 3812-3830.
9. Tung RL (2007) The Human Resource Challenge to Outward Foreign Direct Investment Aspirations From Emerging Economies: The Case of China. International Journal of Human Resource Management 18: 868-889.

10. Dunning JH (1981) International production and The Multinational Enterprise Allen \& Unwin, London.

11. Child J, Marinova S (2014) The Role of Contextual Combinations in the Globalization of Chinese Firms. Management and Organization Review 10 347-371.

12. Luo Y, Tung R (2007) International Expansion of Emerging Market Enterprises: A Springboard Perspective. Journal of International Business Studies 38: 481 498.

13. Child J, Rodrigues SB (2005) The Internationalization of Chinese Firms: A Case for Theoretical Extension. Management and Organization Review 1: 381-410.

14. Deng P (2004) Outward Investment by Chinese MNCs: Motivations and Implications. Business Horizons 47: 8-16.

15. Deng $P$ (2009) Why do Chinese firms tend to acquire strategic assets in international expansion? Journal of World Business 44: 74-84.

16. Rui H, Yip GS (2008) Foreign Acquisitions by Chinese Firms: A Strategic Intent Perspective. Journal of World Business 43: 213-226.

17. Lyles M, Li D, Yan H (2014) Chinese Outward Foreign Direct Investment Performance: The Role of Learning. Management and Organization Review 10: $411-437$

18. Luo Y, Rui H (2009) An ambidexterity perspective toward multinational enterprises from emerging economies. Academy of Management Perspectives 23: $49-70$.

19. Luo Y, Xue Q, Han B (2010) How emerging market governments promote outward FDI: Experience from China. Journal of World Business 45: 68-79.

20. Buckley PJ, Clegg LJ, Cross AR, Liu X, Voss H, et al. (2007) The Determinants of Chinese Outward Foreign Direct Investment", Journal of International Business Studies 38: 499-518.

21. Li MH, Cui L, Lu J (2014) Varieties in state capitalism: Outward FDI strategies of central and local state-owned enterprises from emerging economy countries. Journal of International Business Studies 45: 980-1004.

22. Cui L, Jiang F (2009) FDI entry mode choice of Chinese firms: A strategic behavior perspective. Journal of World Business 44: 434-444.

23. Cui L, Jiang F (2012) State ownership effect on firms' FDI ownership decisions under institutional pressure: A study of Chinese outward-investing firms. Journal of International Business Studies 43: 264-284.

24. Buckley PJ, Cross AR, Tan H, Liu X, Voss H (2006) An Examination of Recent Trends in Chinese Outbound Direct Investment. CIBUL Working Paper. University of Leeds, Leeds.

25. Chen D, Paik Y, Park SH (2010) Host-country policies and MNE management control in IJVs: Evidence from China. Journal of International Business Studies. 41: $526-537$

26. Slangen AHL (2013) Greenfield or acquisition entry? The roles of policy uncertainty and MNE legitimacy in host countries. Global Strategy Journal. 3 262-280.

27. Fang Y, Wade M, Delios A, Beamish PW (2013) An exploration of multinational enterprise knowledge resources and foreign subsidiary performance. Journal of World Business 48: 30-38.

28. Zhang R (2007) Raising Haier. Harvard Business Review 85: 141-146.

29. Sun SL, Peng MW, Ren B, Yan D (2012) A comparative ownership advantage framework for cross-border M\&As: The rise of Chinese and Indian MNEs. Journal of World Business 47: 4-16.

30. Ghauri PN, Buckley PJ (2003) International mergers and acquisitions: Past present and future. Advances in Mergers and Acquisitions 2: 207-229.

31. Harzing AW, Pudelko M (2013) Language competencies, policies and practices in multinational corporations: A comprehensive review and comparison of Anglophone, Asian, Continental European and Nordic MNCs. Journal of World Business 48: 87-97.

32. Yamazaki Y (2010) Expatriate adaptation: A fit between skills and demands among Japanese expatriates in USA. Management International Review 50: 81-108. 